\title{
Clean living behavior to support optimal growth and development for children in Simalungun Regency
}

\author{
Suri Mutia Siregar ${ }^{*}$, Amalia Meutia ${ }^{1}$, Samerdanta Sinulingga ${ }^{2}$, Lisa Marlina $^{3}$ \\ ${ }^{1}$ Department of Psychology, Faculty of Psychology, Universitas Sumatra Utara \\ ${ }^{2}$ Department of Tourism, Faculty of Cultural Sciences, Universitas Sumatra Utara \\ ${ }^{3}$ Department of Management, Faculty of Economics and Business, Universitas Sumatra \\ Utara \\ *Email: surisiregar1@gmail.com
}

\begin{abstract}
Nagori Parik Sabungan is a village located in Dolok Pardamean District, Simalungun Regency. The location of the village is located within the coverage area of Lake Toba, so it has the potential to develop into a tourist destination village. However, this village still has several obstacles to develop tourism, one of which is the low awareness of the community to handle waste properly. This service aims to shape the behavior of LISA (See Garbage Take) in 100 children at the Nagori Parik Sabungan Nature School, so that it can help improve environmental hygiene in the village area and instill clean habits in children. Formation of LISA behavior is done by modifying economic token type behavior. An economic token is a method in which a person or group of people can get a token every time he displays the desired behavior. The series of service activities was held for approximately 29 days. As a result, 50\% of participants children already understand the adverse effects of improper waste management, and $100 \%$ of child participants are able to display LISA behavior during the activity
\end{abstract}

Keyword: Behavior Modification, LISA, Trash, Economic Tokens, Tourism

\begin{abstract}
Abstrak
Nagori Parik Sabungan merupakan salah satu desa yang terletak di Kecamatan Dolok Pardamean, Kabupaten Simalungun. Lokasi desa terletak di dalam wilayah cakupan Danau Toba, sehingga memiliki potensi untuk berkembang menjadi desa tujuan wisata. Namun demikian, desa ini masih memiliki beberapa kendala untuk mengembangkan pariwisata, salah satunya adalah rendahnya kesadaran masyarakat untuk melakukan penanganan sampah secara tepat. Pengabdian ini bertujuan untuk membentuk perilaku LISA (Lihat Sampah Ambil) pada 100 anak-anak di Sekolah Alam Nagori Parik Sabungan, sehingga dapat membantu meningkatkan kebersihan lingkungan di wilayah desa serta menanamkan kebiasaan hidup bersih pada anak-anak. Pembentukan perilaku LISA dilakukan dengan metode modifikasi perilaku tipe token ekonomi. Token ekonomi adalah suatu metode dimana seseorang atau sekelompok orang dapat memperoleh token setiap kali ia menampilkan perilaku yang diinginkan. Rangkaian kegiatan pengabdian diselenggarakan selama kurang lebih 29 hari. Hasilnya, 50\% peserta anak sudah memahami dampak buruk dari penanganan sampah yang tidak tepat, dan $100 \%$ peserta anak sudah mampu menampilkan perilaku LISA selama kegiatan berlangsung
\end{abstract}

Kata Kunci: Modifikasi Perilaku, LISA, Sampah, Token Ekonomi, Pariwisata

\section{PENDAhuluan}

Kabupaten Simalungun merupakan kabupaten terluas ketiga di Provinsi Sumatera Utara setelah Kabupaten Langkat dan Kabupaten Mandailing Natal, dengan luas wilayah 4.372,50 Km2 atau 6.12 persen dari luar Provinsi Sumatera Utara. Kabupaten Simalungun berbatasan dengan 8 (delapan) kabupaten / kota yaitu sebelah utara Kabupaten Simalungun berbatasan dengan Kabupaten Serdang Bedagai dan Deli Serdang, sebelah selatan berbatasan dengan Kabupaten Toba Samosir dan Kabupaten Samosir, sebelah barat berbatasan dengan Kabupaten Karo dan sebelah 
timur berbatasan dengan Kabupaten Asahan dan Batu Bara serta dengan Kota Pematang Siantar yang dikelilingi oleh wilayah Kabupaten Simalungun. Secara astronomis Kabupaten Simalungun terletak diantara 020 36" - 030 18" Lintang Utara dan 980 32" - 990 33" Bujur Timur dan berada pada ketinggian 0 - 1400 meter. Secara administratif, Kabupaten Simalungun memiliki 31 Kecamatan, 286 Nagori (desa), dan 27 kelurahan. (Republik Indonesia, 2016). Berdasarkan data yang tercantum dalam Laporan Kinerja Pemerintah Kabupaten Simalungun Tahun 2016 (Republik Indonesia, 2016), Kabupaten Simalungun memiliki beberapa potensi ekonomi daerah, diantaranya adalah : (1) Tanaman Bahan Makanan : Kabupaten Simalungun merupakan penghasil padi terbesar di Provinsi Sumatera Utara, dimana pada tahun 2016 mampu menghasilkan Padi Sawah sebesar 583.016 ton dan Padi Gogo sebesar 35.070 ton. Tanaman bahan makanan lainnya adalah jagung, kedelai, kacang tanah, kacang hijau, ubi kayu, dan ubi jalar; (2) Tanaman Hortikultura : Kabupaten Simalungun memiliki beberapa komditi sayuran yang dikembangkan yaitu bawang merah, bawang putih, cabai, kubis, kentang, jeruk, pisang, dan nanas; (3) Perkebunan : Kabupaten Simalungun memiliki potensi perkebunan rakyat antara lain karet dan kelapa sawit; (4) Peternakan : Kabupaten Simalungun memiliki potensi peternakan rakyat yang tesebar di beberapa kecamatan meliputi sapi, kambing, domba, kerbau, babi, ayam ras, ayam bukan ras, ayam ras petelur, dan itik; (5) Perikanan : Kabupaten Simalungun memiliki potensi perikanan yang bersumber dari Danau Toba, kolam dan sawah. Selain 5 (lima) potensi ekonomi daerah diatas, Kabupaten Simalungun juga berupaya untuk mengembangkan destinasi pariwisata dan pelestarian budaya lokal, salah satunya dengan memanfaatkan obyek wisata Danau Toba.

\section{METODE PELAKSANAAN}

Berdasarkan perumusan masalah mitra di Nagori Parik Sabungan sebagai daerah tujuan wisata, maka solusi dan target luaran yang ditawarkan adalah : 1. Masalah : Anak - anak perlu mendapatkan pemahaman mengenai perilaku hidup bersih untuk mendukung tumbuh kembang yang optimal, serta mempersiapkan mereka untuk menjadi masyarakat sadar wisata di masa depan. Solusi : Sosialisasi Perilaku Hidup Bersih dan Sehat di Nagori Parik Sabungan. Dampak : Anak anak mendapatkan pemahaman mengenai pentingnya menerapkan kebiasaan hidup bersih dan sehat, serta mendapatkan keterampilan untuk menunjukkan perilaku hidup bersih dan sehat. Metode Pelaksanaan : Melakukan diskusi dengan anak-anak serta memberikan keterampilan CTPS (Cuci Tangan Pakai Sabun), sikat gigi yang baik dan benar, serta membersihkan kuku pada tanggal 1 Agustus 2019. 2. Masalah : Anak - anak perlu berkumpul untuk belajar mengenai penanganan sampah serta perilaku hidup bersih dengan cara yang menyenangkan. Solusi : Membuat kegiatan bermain dengan anak, yaitu "Sekolah Alam Nagori Parik Sabungan" yang dilakukan di areal hutan wisata desa. Dampak : Anak-anak menunjukkan semangat yang besar untuk mengikuti setiap kegiatan yang diselenggarakan oleh Sekolah Alam Nagori Parik Sabungan. Metode Pelaksanaan : Melakukan sosialisasi mengenai kegiatan yang diselenggarakan oleh Sekolah Alam Nagori Parik Sabungan pada tanggal 18 Juli 2019, serta menyelenggarakan kegiatan di areal hutan wisata pada tanggal 23 Juli 2019, 25 Juli 2019, 1 Agustus 2019, 6 Agustus 2019, 7 Agustus 2019, dan 12 Agustus 2019. 3. Masalah : Anak - anak perlu diperkenalkan dengan perilaku pemahaman sampah yang tepat, agar di masa yang akan datang dapat membantu mengembangkan potensi wisata di desa. Solusi : Memberikan edukasi kepada anak mengenai sampah dan penanganan yang tepat untuk sampah. Dampak : Anak - anak memahami mengenai pentingnya memperhatikan permasalahan sampah di lingkungan sekitar, serta cara menangani sampah secara sederhana. Metode Pelaksanaan : Melakukan sosialisasi serta praktek pemilahan sampah organik dan anorganik di Sekolah Alam Nagori Parik Sabungan pada tanggal 1 Agustus 2019. 4. Masalah : Anak-anak perlu mendapatkan pembentukan perilaku LISA (Lihat Sampah Ambil) sebagai salah satu usaha untuk mengumpulkan sampah yang berserakan di 8 desa, serta membiasakan anak untuk membuang sampah pada tempatnya. Dampak : Anak - anak memiliki kemauan untuk menampilkan perilaku LISA, serta menunjukkan perilaku LISA selama kegiatan berlangsung. Metode Pelaksanaan : Melakukan sosialisasi mengenai perilaku LISA beserta manfaatnya, serta 
melakukan modifikasi perilaku terhadap anak dengan menggunakan metode token ekonomi pada tanggal 6-12 Agustus 2019.

\section{HASIL DAN PEMBAHASAN}

Seluruh kegiatan pokok pengabdian masyarakat di Nagori Parik Sabungan telah dilakukan oleh tim pengabdian dengan bantuan 15 mahasiswa yang tergabung dalam kelompok KKN Bersama BKS PTN Barat, beserta perangkat desa setempat. Adapun rincian dari kegiatan yang telah dilakukan adalah sebagai berikut : 1. Sosialisasi Perilaku Hidup Bersih dan Sehat pada 70 Anak di Nagori Parik Sabungan Kabupaten Simalungun. Kegiatan ini dilakukan pada tanggal 1 Agustus 2019

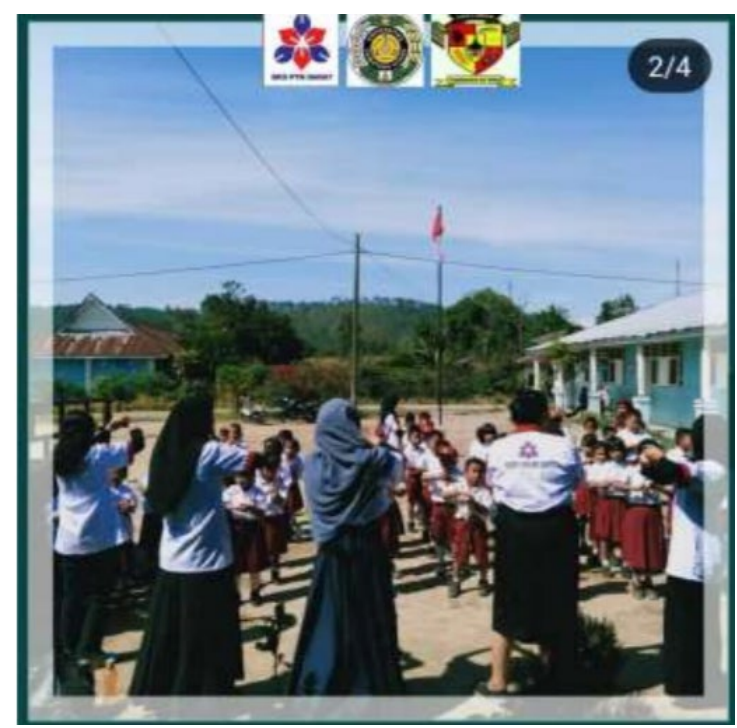

Gambar 3.1 Sosialisasi Perilaku Hidup Bersih dan Sehat

Tim pengabdian dibantu oleh mahasiswa yang tergabung dalam kelompok KKN Bersama BKS PTN Barat melakukan diskusi Perilaku Hidup Bersih dan Sehat kepada anak-anak. Tim memberikan sejumlah pertanyaan kepada anak-anak untuk mengetahui wawasan mereka mengenai perilaku hidup bersih dan sehat, serta memberikan ceramah mengenai pentingnya membentuk perilaku hidup bersih dan sehat pada anak-anak. Setelah melaksanakan kegiatan diskusi, tim kemudian memberikan pelatihan sederhana kepada anak-anak mengenai CTPS (Cuci Tangan Pakai Sabun), sikat gigi yang baik dan benar, serta membersihkan kuku. Tim juga membawa beberapa peralatan untuk praktek hidup bersih dan sehat seperti sabun, sikat gigi, odol, dan gunting kuku. Selanjutnya, seluruh peserta anak dengan dipandu oleh tim bersamasama mempraktekkan cuci tangan pakai sabun, sikat gigi, dan membersihkan kuku.

\section{KESIMPULAN}

Dibab ini tuliskan kesimpulan dari hasil kegiatan pengabdian atau penelitian sesuai hasil yang diperoleh. Banyak kesimpulan sesuai dengan banyak tujuan yang dituliskan pada bagian pendahuluan.

\section{UCAPAN TERIMAKASIH}

Ucapan Terima Kasih kepada Lembaga Pengabdian kepada Masyarakat Universitas Sumatera Utara yang telah Menfasilitasi Pelaksanaan Kuliah Kerja Nyata Tahun 2019 


\section{DAFTAR PUSTAKA}

Hardianti, Wildam, dan Nasrulhaq. 2017. Implementasi LISA (Lihat Sampah Ambil) Program Makassarta Tidak Rantasa di Universitas Muhamadiyah Makassar. Jurnal Inovasi Kebijakan : Matra Pembaruan 1 (3) (2017) : 189 - 200

Republik Indonesia. 2011. Seri Bacaan Orangtua : Mengembangkan Perilaku Sehat Pada Anak Usia 2 - 4 Tahun. Direktorat Pembinaan Pendidikan Anak Usia Dini, Direktorat Jenderal Pendidikan Anak Usia Dini Nonformal dan Informal Kementrian Pendidikan Nasional

2016. Laporan Kinerja Pemerintah Kabupaten Simalungun Tahun 2016. Pemerintah Kabupaten Simalungun 